\title{
Structure features and structural transformations of the maxillary bones in the Baikal cottoid fish
}

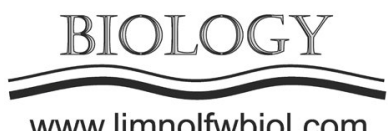

www.limnolfwbiol.com

\author{
Tolmacheva Yu.P.*, Bun M.M. \\ Limnological Institute, Siberian Branch of the Russian Academy of Sciences, Ulan-Batorskaya Str., 3, Irkutsk, 664033, Russia
}

\begin{abstract}
In this paper, we study morphogeometric parameters and histostructure of maxillary bones in three coastal Baikal Cottoidei species belonging to different trophic groups. The results of the study revealed that the main trend in the transition from benthography to ichthyography is the sequential elongation of jaws and reduction in the mouth thrust accompanied by a consistent change in the form and internal structure of bone elements. A detailed analysis of data revealed that the changes mostly concern additional morphological structures (processes) of the bones directly connected with musculoligamentous apparatus and experiencing the highest tension during the functioning of the maxillary system. The distinctive features of the structural transformations maxillary bones in different fishes is a consequence of the uneven effect of power load that changes when the body adapts to certain habitat conditions.
\end{abstract}

Keywords: cottoid fish, maxillary apparatus, morphogeometric parameters, histostructure, structural adaptation, external power load

\section{Introduction}

The study of trophic adaptations in Baikal fish represents a bulk of closely related species. This is very interesting due to the peculiarities of the Baikal ecosystem owing to its age and diversity of underwater landscapes. The cottoid group, whose representatives occupy at present practically all biotopes and trophic niches of the lake, has a special status amongst the Baikal fish. Three species of the family Cottidae, Paracottus knerii, Leocottus kesslerii and Batrachocottus baicalensis (Taliev, 1955; Sideleva, 2003), inhabit the littoral zone (from the water edge up to the depths of 250-300 m). The study of dietary habits within this biotopical group revealed two main trends of trophic adaptation, allowing these species to coexist in a single biotope: zoophagy and zoophagy + ichthyophagy (Taliev, 1955; Sideleva and Mekhanikova, 1990; Sideleva, 2003; Dzyuba, 2004; Miyasaka et al., 2006; Tolmacheva, 2008). Each species formed its morphofunctional features in the structure of the anterior digestive system as a result of adaptation to a specific trophic behavior (Taliev, 1955; Yabe, 1985; Sideleva and Mekhanikova, 1990; Sideleva, 2003; Tolmacheva, 2010). As any change in the function and structure of the system is followed, above all, by certain changes in its separate parts, it is relevant to apply the detailed approach to study latent regularities of these structural transformations in the closely related species of fish.
The present paper concerns a comparative morphometric and histological study of the maxillary bones and analysis of potential causes of their structural transformations in the Baikal cottoid fish from various trophic groups.

\section{Materials and research methods}

Osteological specimens of the maxillary bones of three species of cottoid fish from the Baikal littoral zone, Paracottus knerii (Dyb., 1874), Leocottus kesslerii (Dyb., 1874) and Batrachocottus baicalensis, were used in this study. Thirty specimens of each species were examined in total.

The standard methods for osteological analysis were used to study the shape of the maxillary bones (Standard methods.... 1976). The soft tissues were removed from the fish skulls with a $10 \%$ solution of $\mathrm{NaOCl}$; the cleaned bones were stored in glycerol. The comparative analysis included 16 measurements (\% of the bone length) of the anguloarticulare, dentale and praemaxillare. The method for constructing allometric networks similar to the approach used previously in analyzing the variability of the body shape of fish (Strauss and Bookstein, 1982; Strauss and Fuiman, 1985; Tolmacheva, 2011) was used to create geometric structures of the maxillary bones. The geometric design was performed via the Autocad 2010 software (http:// www.autodesk.ru) (Fig. 1). 

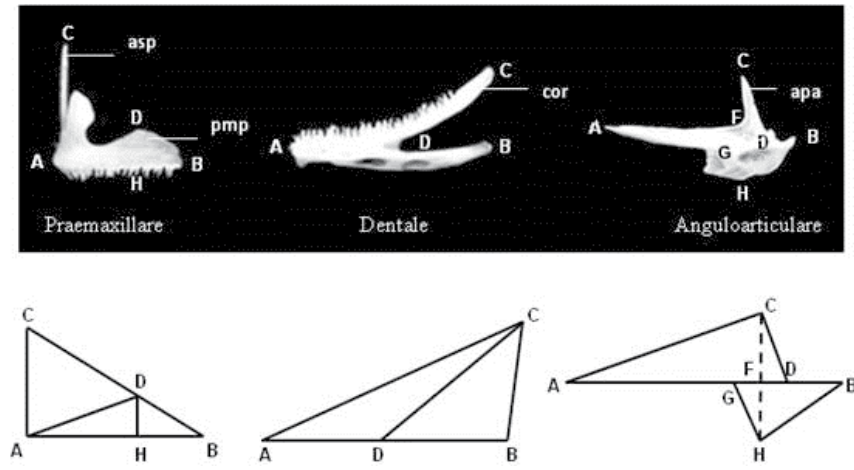

The histological structures of the maxillary tissues were studied according to the standard methods (Merkulov, 1969). The material was fixed in a $10 \%$ buffer formalin solution, which was decalcified with a $5 \%$ nitric acid solution and put into wax-paraffin. The $10-\mu \mathrm{m}$ thick sections were stained with hematoxylineosin. The anatomical structure of each bone was presented as longitudinal and transverse sections. Morphometric analysis of the specimens was performed using a binocular light microscope (S. Zeiss) and ImageScope Color Image Analysis software (Moscow, 2008). The following parameters were chosen for the analysis: bone area, cartilage and bone cavity (thousand $\mu^{2} /$ area of one field of view). The average area of one field of view was $1.73 \mu \mathrm{m}^{2}$ at 125 -fold magnification. Each specimen was analyzed in 10 areas of view.

\section{Results and disscusion}

The objects studied were closely related species of cottoid fish that inhabit the littoral zone of Lake Baikal and have a similar feeding behavior. The previous investigations of the maxillary apparatus of these fish revealed the growth of its linear parameters in the following direction: Paracottus knerii - Leocottus kesslerii - Batrachocottus baicalensis. This was due to the consumption of prey with different size and incomplete transition to ichthyophagy (Tolmacheva, 2010) (Fig. 2).

Morphogeometrical parameters. The morphometric analysis together with a geometric approach made the set of linear measurements more illustrative and enabled to investigate the simple regularities that are not always apparent without visualization (Fig. 2):

Upper jaw (praemaxillare + maxillare). Elongation of the upper jaw is followed by a consistent reduction of its ascending process of praemaxillare. This is often observed in other fish species. The relative height of the ascending process in the zoophage $P$. knerii and $L$. kesllerii was $81 \%$ and $70 \%$, respectively, of the praemaxillare length, whereas it was $52 \%$ in the facultative ichthyophage $B$. baicalensis.

Lower jaw (dentale + anguloarticulare). The main differences in the relative parameters of the lower jaw amongst the studied species are limited to the reduction of the bone height. The relative height
Fig. 1. The construction scheme of morphogeometric design of the maxillary bones in cottoid fish: a) the measurement scheme in osteological analysis; b) projection of measurements (in \% of bone length) in morphgeometric design. Legend: Praemaxillare: asp - pmx ascending process, pmp - pmx maxillary process, (AC - asp height, AH - pmp location, DH - pmp height); Dentale: cor - den coronoid process ( $\mathrm{BC}$ den height, $\mathrm{AC}$ - location of the cor posterior end, DC - cor length, BD - den notch depth); Articulare: apa - superior art process $(\mathrm{CH}$ - art height, $\mathrm{AD}$ - location of suprascapular notch (base of superior process), CD - height of superior process, $\mathrm{CF}$ - location of superior process: AG location of inferior notch).

of the dentale in $P$. knerii and L. kesllerii was 41.6 and $43 \%$, respectively, and $35 \%$ - in B. baicalensis. It is noteworthy that the anterior process of anguloarticulare is consistently retracted $(70 \%, 77 \%$ and $71 \%$ in $P$. $\kappa n e r i i, L$. kesllerii and B. baicalensis, respectively) and dislocated in a more horizontal position (Fig. 2). The anterior process $(70-71 \%)$ and the lower process (62\%) remain in unaltered position.

The measurements show that the consistent elongation of the jaw and reduction of the mouth protrusion in the studied species is followed by an appropriate change in mouth shape and the ratio of its morphological structures (Taliev, 1955; Sideleva and Mekhanikova, 1990; Sideleva, 2003; Tolmacheva, $2008 ;$ 2010). The power load, which changed during evolution, is the main factor that affects the morphogenesis of the bone tissue (Wolff, 1892). Hence, a transformation of the bone shape should primarily occur in the regions of the maximum stress during the functioning of the maxillary apparatus.

The protrusion of the upper jaw in the cottoid fish results from gliding the ascending processes of praemaxillare along the ethmoideum. The degree of the protrusion depends on two interdependent features: the length of the praemaxillare and the height of the ascending process (Gregory, 1933; O'Kamura, 1970; Voskoboinikova, 1986). The ascending processes of praemaxillare carry the maximum power load, resulting
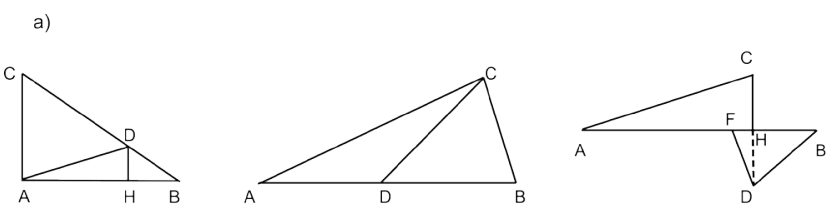

b)
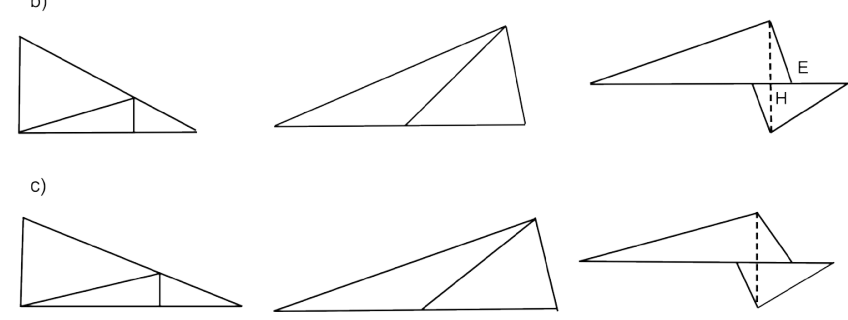

Fig. 2. Morphogeometric design of jaw apparatus bones in littoral species of Cottoidei belonging to diffirenent trophic groups: a) Paracottus knerii; b)Leocottus kesslerii; c) Batrachocottus baicalensis. 
from the functioning of the maxillary apparatus in the anamniotes (Lebedkina, 1980). An elongation of the praemaxillare in ichthyophages significantly increases the pressure on the ascending processes and, thus, leads to their gradual reduction.

The lesser degree of protrusion requires more efforts to close the mouth (Aleev, 1963). This process is carried out with the musculus adductor mandibulae (A2, A3 and AW), whose portions are predominantly attached to the internal side of the anguloarticulare and the anterior process (Dobben, 1935; Yabe, 1985). The transformation of the anguloarticulare shape and the consistent dislocation of the anterior process in a horizontal plane is due to the increasing power stress from the muscles. In turn, the dislocation of the anterior process of anguloarticulare in a horizontal plane reduces the dentale that contacts with it in the region of the coronoid process.

Histostructure. The histological analysis shows that rough fibrous tissue typical of the bony fish represents the microstructure of maxillary bones in the studied species (Meunier and Desse, 1986). There are compacted portions of cartilaginoid tissue in the contact areas. The surface of each bone represents a compact structure above bone cavities that are connected by anastomoses and form a single network (Fig. 3a). Inside the cavities, there are fragments of osteoblasts that were destroyed during the preparation of the specimens.

The number and size of the cavities significantly vary within the same bone (Fig. 3a, Fig. 3b). E.g., many small cavities, making $30-43 \%$ of the total area in a vertical section of the bone, represent the network structure inside the bones. The internal structure of the processes (ascending process of praemaxillare, anterior process of anguloarticulare and coronoid process of dentale) represent a single large cavity (50-69\% in area) that is encircled by a layer of a dense coarse fibrous tissue.

Bias in the external mechanical load on the formation of the bone tissue induces the heterogeneity of the network structure (the bone cavities become fewer and larger) in different portions of the same bone. In the study of the internal structure of the maxillary apparatus in the Scaridae, the area of the cavities increased in the region of the maximum stress (Bogachik, 1999). We determined this regularity in the microstructure of the processes of the maxillary bones that are the most affected by the muscular-ligamentous apparatus.

\section{Conclusion}

Thus, changes in functional requirements in a specific environment cause the adaptive transformations of the maxillary apparatus of the fish. The main trend observed in the Baikal cottoid fish at the transition from benthos feeding to ichthyophagy is a consistent elongation of the jaw and reduction of the upper jaw protrusion followed by an appropriate change in the shape, size and internal structure of the main bone elements. The transformation of the bone shape and
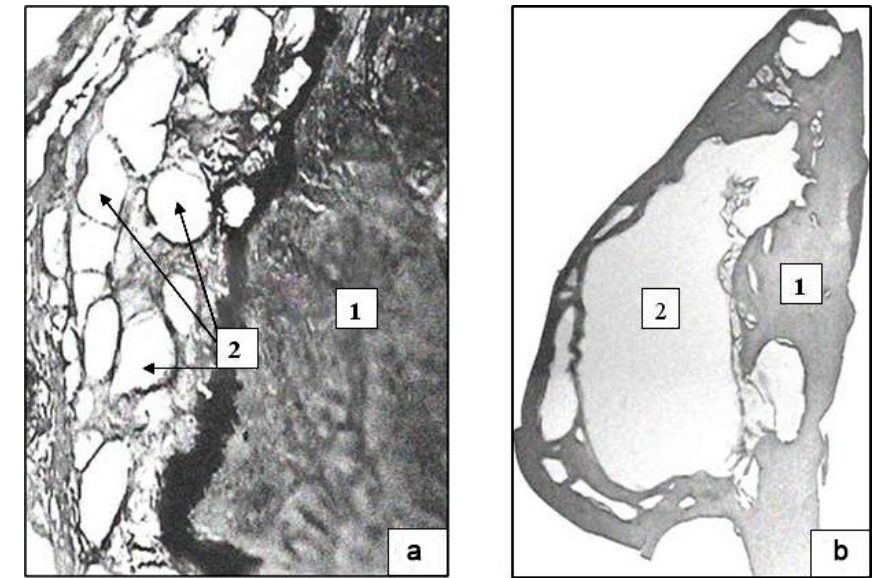

Fig. 3. Anguloarticulare histostructure of the bighead sculpin Batrachocottus baicalensis: a) transverse section of the bone; b) transverse section of the anguloarticulare superior process. 1 - compact tissue, 2 - medulary cavities. Magnification x125.

internal structure occurs in the regions of the maximum stress that occurs during the functioning of the maxillary apparatus. It mainly concerns supplementary elements (processes) of the maxillary bones that are directly connected to the muscular-ligamentous apparatus and most exposed to external forces. Overall, the peculiarities of the structural transformations of the maxillary system in different species is a result of uneven power load that changes during adaptation of an organism to a specific environment.

\section{Acknowledgements}

The work was performed within the project No. 0345-2019-0002.

\section{References}

Aleev Yu.G. 1963. Funktsional'nyye osnovy vneshnego stroyeniya ryb. Moscow: Publishing House of the USSR Academy of Sciences. (in Russian)

Bogachik T.A. 1999. Histological analysis of the microstructure of the jaw and pharyngeal apparatus of two species of scar fish (Scaridae). In: Lobkov V.A. (Ed.), Razvitiye zoologicheskikh issledovaniy $\mathrm{v}$ Odesskom universitete. Odessa, pp. 163-174. (in Russian)

Dobben W.N. 1935. Uber der Kiefermechanismus der Knochenfishe. Archives Néerlandaises de Zoologie [Dutch Archives of Zoology] 50: 1-72. (in German)

Dzyuba E.V. 2004. Issledovaniye pishchevykh strategiy pelagicheskikh ryb Baykala. Cand. Sc. Dissertation, Papanin Institute for Biology of Inland Waters RAS, Borok, Russia. (in Russian)

Gregory W.K. 1933. Fish skulls. A study of the evolution of natural mechanism. Transactions of the American Philosophical Society 23: 75-481.

Lebedkina N.S. 1980. Leading traits in phylogenetics. In: Morfologicheskiye aspekty evolyucii. Moscow, pp. 53-64. (in Russian)

Merkulov G.A. 1969. Kurs patogistologicheskoy tekhniki. Leningrad: Meditsyna. (in Russian)

Meunier F.J., Desse G. 1986. Les hyperostose les Téléostéens: description, histolog et problémes étiologique. Ichthyophysiological Acta 10: 130-141. (in French) 
Miyasaka H., Dzyuba Ye.V., Genkai-Kato M. et al. 2006. Feeding ecology of two planktonic sculpins, Comephorus baicalensis and Comephorus dybowskii (Comephoridae), in Lake Baikal. Ichthyological Research 53: 419-422.

O'Kamura O. 1970. Studies of the Macrouroid fishes of Japan. Morphology, ecology and phylogeny. Reports of the USA Marine Biological Station 17: 33.

Sideleva V.G. 2003. The endemic fishes of Lake Baikal. Leiden: Backhuys Publ.

Sideleva V.G., Mechanikova I.V. 1990. Food specialization and evolution of bullhead fish (Cottoidei) in Lake Baikal. Trudy Zoologicheskogo Instituta [Proceedings of Zoological Institute of the USSR Academy of Sciences] 222: 144-161. (in Russian)

Tipovyye metodiki issledovaniya produktivnosti vidov ryb v predelakh ikh arealov. 1976. Vilnius: Moxlas. (in Russian)

Strauss R., Bookstein F.L. 1982. The truss: body form reconstructions in morphometrics. Systematic Zoology 31: 113-135. DOI: 10.1093 /sysbio/31.2.113

Strauss R., Fuiman L. 1985. Quantitative comparisons of body form and allometry in larval and adult Pacific sculpins (Teleostei: Cottidae). Canadian Journal of Zoology 63: 15821589. DOI: $10.1139 / \mathrm{z} 85-234$

Taliev D.N. 1955. Bychki-podkamenshchiki Baykala. Moscow-Leningrad: Publishing House of the USSR Academy of Sciences. (in Russian)
Tolmacheva Yu.P. 2008. Comparative characteristic of feeding of three species of cottoidei in the littoral of southern Baikal (Cape Berezovyi). Journal of Ichthyology 48: 499-504. DOI: $10.1134 /$ S0032945208070035

Tolmacheva Yu.P. 2010. Structure of the mouth opening and pharyngeal apparatus in three species of Baikal Cottoidei in relation to their feeding. Journal of Ichthyology 50: 65-72. DOI: $10.1134 / S 0032945210011008 X$

Tolmacheva Yu.P. 2011. Geometricheskaya konstruktsiya $\mathrm{v}$ issledovanii stroyeniya chelyustnogo apparata ryb. In: 1st International Scientific-Practical Conference "Sovremennyye Zoologicheskiye Issledovaniya $\mathrm{v}$ Rossii i Sopredel'nykh Stranakh" ["Modern Zoological Research in Russia and Neighboring Countries"], pp. 138-142. (in Russian)

Voskoboinikova O.S. 1986. Evolutionary transformations of the visceral skeleton and phylogeny issues of nototheniidae fish (Nototheniidae). Trudy Zoologicheskogo Instituta [Proceedings of Zoological Institute of the USSR Academy of Sciences] 153: 46-66. (in Russian)

Wolff J. 1892. Das Gesetz der Transfomation der Knochen. Berlin: Hirshwald. (in German)

Yabe M. 1985. Comparative osteology and miology of the superfamily Cottoidea (Pisces: Scorpaeniformes), and its philogenetic classification. Memoirs of the Faculty of Fisheries Hokkaido University 32: 1-130. 